\title{
Hiperkalsemi ve Çoklu Patolojik Kemik Fraktürü ile Başvuran Akut Lenfoblastik Lösemi
}

\author{
Hypercalcemia and multiple Pathologic Bone Fracture in Acute Lymphoblastic Leukemia
}

\author{
Ahmet GİRGEÇ ${ }^{1}$, Fatih TEMİ ${ }^{2}$, Sadık YURTTUTAN ${ }^{2}$, Zübeyde DINÇER ${ }^{1}$, Osman \\ NURI ÖZEN ${ }^{1}$, Can ACIPAYAM ${ }^{2}$
}

\begin{abstract}
${ }^{1}$ Ar. Gör .Dr. Kahramanmaraş Sütçü İmam Üniversitesi Tıp Fakültesi, Çocuk Sağlığı ve Hastalıkları Anabilim Dalı, KAHRAMANMARAŞ ${ }^{2}$ Doç. Dr. Kahramanmaraş Sütçü İmam Üniversitesi Tip Fakültesi, Çocuk Sağlığı ve Hastalıkları Anabilim Dalı, KAHRAMANMARAŞ
\end{abstract}

Özet

Hiperkalsemi, bazı lenfoproliferatif hastalıklarda sıkça görülmesine rağmen çocukluk çağı akut lenfoblastik lösemilerinde nadir bir komplikasyondur. Bu yazıda hiperkalsemi ve çoğul patolojik kemik kırıkları ile başvuran ve akut lösemi tanısı konulan 8 yaşında bir erkek olgu sunulmuştur. Hiperkalsemi etkeni olabilecek tüm nedenler araştırıldı ve laboratuar testler normal bulundu. Hiperkalsemi, intravenöz izotonik sodyum klorür, furosemid, steroidler ve bifosfonatlar ile tedavi edildi. Hiperkalsemi, çocukluk çağı akut lenfoblastik löseminin başlangıç laboratuvar bulgusu olabilir. Tekrarlayan laboratuvar ve periferik yayma incelemeleri hiperkalseminin ayırıcı tanısında önemlidir.

Anahtar Kelimeler: Akut lenfoblastik lösemi, hiperkalsemi, patolojik kirık

\section{GíRiş}

Çocuklarda hiperkalsemi hastanın yaşına göre ve laboratuvar referans aralığına göre değişebilmekle birlikte serum kalsiyum düzeyinin $11 \mathrm{mg} / \mathrm{dl}$ veya iyonize kalsiyum düzeyinin $5,5 \mathrm{mg} / \mathrm{dl}$ üzerinde olması durumudur. 10.5-12 mg/dl arası hafif hiperkalsemi olarak kabul edilirken, $14 \mathrm{mg} / \mathrm{dl}$ üzeri hayatı tehdit edebilecek düzey olarak kabul edilmektedir. Hiperkalseminin en sık nedenleri paratiroid adenomu, paratiroid hiperplazisi, sekonder veya tersiyer olarak ise kronik böbrek yetmezliği ve $D$ vitamini eksikliğidir. Ayrıca granulamatöz hastalıklar (tüberküloz, sarkodoz, hodgkin lenfoma), hipofosfotemi, maligniteler de diğer hiperkalsemi nedenleri arasında sayılmaktadır (1). Klinik olarak hiperkalsemi; kas güçsüzlüğü, nefrolitiyasiz, poliüri, polidipsi, patolojik kırıklar, iştahsızlık, bulantı, kusma, dehidratasyon, konfüzyon, stupor ve komaya kadar değişen durumlarla karşımıza çıkabilmektedir (2). Çocuklarda hiperkalsemi acil bir durum olup birçok hastalığın klinik bulgusu olarak görülebilir. Bu yazıda hiperkalsemiyle başvuran çoklu kemik fraktürü olan ve yapılan tetkikler sonucu akut lenfoblastik lösemi (ALL) tanısı konulan 8 yaşındaki erkek olguyu paylaşmak istedik.

\section{OLGU}

8 yaşında erkek hasta 1,5 ay önce yüksekten düşme sonucu dış merkeze başvurduğu ve

İletişim: Dr. Can Acıpayam. KSÜ Tip Fakültesi Çocuk Sağllğı ve Hastalıkları Anabilim Dalı, KAHRAMÁNMARAŞ

DOI:

$10.17517 /$ ksutfd.382098

\section{Abstract}

Hypercalcemia is common in some lymphoproliferative disorders, but is a rare complication of acute lymphoblastic leukemia in childhood. We report a 8 -year-old boy who presented with hypercalcemia and multiple pathologic bone fracture was diagnosed to have acute lymphoblastic leukemia. All the disorders that could be the reason of hypercalcemia and the laboratory tests were within normal limits. Hypercalcemia was treated with intravenous isotonic sodium chloride solution, furosemide and biphosphonates. Hypercalcemia may be a presenting laboratory finding of acute lymphoblastic leukemia in childhood. Repeat laboratory and peripheral blood smear examinations are important for differential diagnosis of hypercalcemia.

Key Words: Acute lymphoblastic leukemia, hypercalcemia, pathologic fracture

vertebralarda 6 adet deplese olmayan fraktür saptanıp, korse ve yatak istirahati önerildiği öğrenildi. Sırt ve sol bacakta ağrı olması üzerine, bakılan tetkiklerinde serum kalsiyumu (Ca) 13,5 mg/ dL saptanan hasta tarafımıza sevk edildi. Hastanın özgeçmişinde; sağlıklı annenin 1.gebeliğinden 1.sağlıklı çocuk olarak normal vajinal yolla doğduğu ve öncesinde bilinen ek hastalığı olmadığı öğrenildi. Anne -baba 2.dereceden akraba olup diğer kardeşler sağlıklıydı. Hastanın yapılan fizik muayenesinde; vücut ağırlığı:27 kg (50-75p), boy: $118 \mathrm{~cm}$ (25-50p), TA:100-70 mm Hg, nabız: 95 atım/dk, torakal bölgede vertebralarda palpasyonla hassasiyet, sol bacakta hareket esnasında ağrı olup diğer sistemik muayenelerinde ek patolojik bulguya rastlanmadı. Biyokimyasal parametrelerinde serum kalsiyumu yüksek $(12,88 \mathrm{mg} / \mathrm{dL})$, parathormon düzeyi düşük $(00 \mathrm{pg} / \mathrm{mL})$ saptandı. HGB $10.5 \mathrm{~g} / \mathrm{dL}$, beyaz küre sayısı $4.580 / \mathrm{mm} 3$, nötrofil sayısı $1.960 / \mathrm{mm} 3$, trombosit sayisı $222000 / \mathrm{mm} 3, \mathrm{LDH} 240 \mathrm{U} / \mathrm{L}$, fosfor $4.9 \mathrm{mg} / \mathrm{dL}$, ürik asit $6 \mathrm{mg} / \mathrm{dL}$, kreatinin $0.41 \mathrm{mg} / \mathrm{dL}$, alkalenfosfataz $108 \mathrm{U} / \mathrm{L}$, diğer elektrolit değerleri, $\mathrm{D}$ vitamin düzeyi ve tiroid fonksiyon testi normal sınırlarda geldi. Çekilen el bileği, iki yönlü akciğer grafisi, kafa grafisinde osteolitik lezyona rastlanmadı. Batın ultrasonografisinde patolojik bulguya rastlanmadı. Hastaya $3500 \mathrm{cc} /$ gün $1 \frac{2}{2}$ izomiks, furosemid infüzyonu başlandı, 12 saat sonra Ca 13,2 mg/dl gelen hastanın tedavisine alendronat eklendi, takipte Ca düzeyi normale geldi. Olguya spontan sol bacak fraktürü olması nedeniyle
Tel : 05334254455
E-Posta : cacipayam@hotmail.com
Geliş Tarihi : 21.01 .2018
Kabul Tarihi : 20.02 .2018 
periferik yayma yapıldı; eritrositler hipokrom ve 1 adet atipik hücre (blast?) saptanması üzerine kemik iliği aspirasyonu yapıldı ve \%90 (çoğunluğu L2 tipi yer yer L1 tipi ) blastlar görüldü ve hastaya ALL tanısı konuldu (Şekil 1). Olgunun takip ve tedavisi devam etmektedir.

Resim 1: Hastanın kemik iliği aspirasyonu yayma görüntüsü.

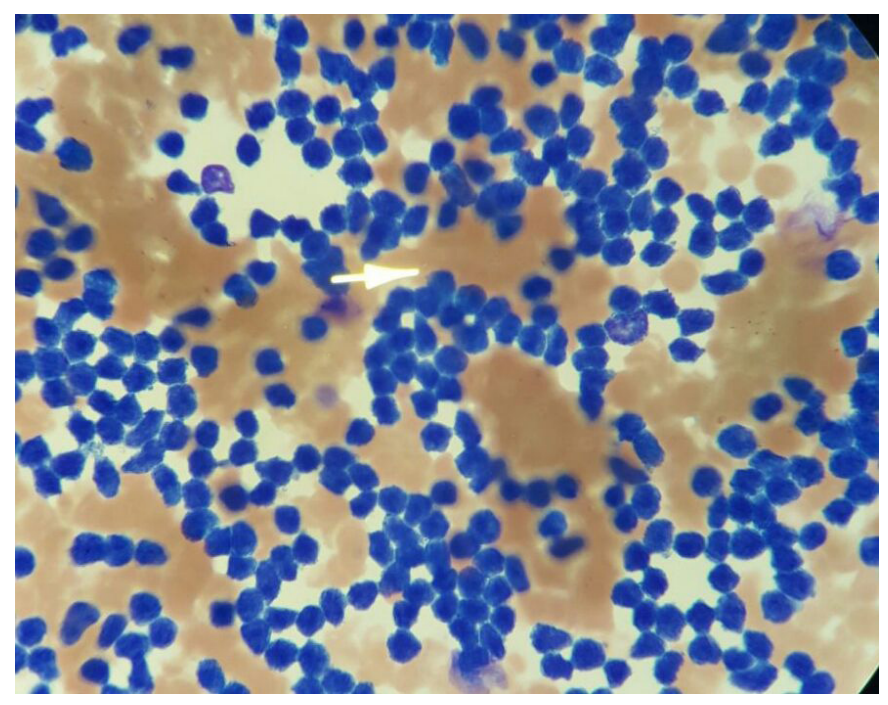

\section{TARTIŞMA}

Hiperkalsemi erişkinlerin aksine çocukluk çağı kanserlerinin nadir görülen bir bulgusudur. Kanserli çocukların \% 1'den azında tanı sırasında hiperkalsemi görülür. Akut lösemi çocuklarda en sık görülen malignitedir (3). Çocuklarda hiperkalsemi ile ilişkili maligniteler; lösemi, lenfoma, rabdomyosarkom, hodgkin ve non-Hodgkin lenfoma, beyin tümörleri ve nöroblastomdur (4). Lösemili çocuklarda hiperkalsemi az sayıda hastada bildirilmiştir (5-8). St. Jude hastanesinde izlenen 2816 lösemisi olan çocuğun sadece 11'inde hiperkalsemi olduğu gösterilmiştir (9). Literatürdeki hiperkalsemi ile başvuran ALL hastalarına bakıldığında ortalama yaşının sekiz olduğu, hastaların çoğunun başvuru sırasında kan sayımlarının normal olduğu ve yine büyük kısmında periferde blast olmadığı dikkat çekmektedir.

Malignite kaynaklı hiperkalseminin iki temel mekanizma olduğu bilinmektedir. Birinci yolda tümör hücreleri kemiğe metaztaz yaparak osteoklastları aktive eder ve kemik yıkımınına sebep olur. Diğer mekanizma ise tümör hücrelerinden salgılanan osteoklastik etmenlerin etkisidir. Osteoklastik kemik yıkımını aktive eden en önemli etmen paratiroid hormonu (PTH) benzeri proteindir. Paratiroid hormon benzeri protein, aynen PTH gibi osteoklastik kemik yıkımını arttırıp hem de distal tübüllerden kalsiyum geri emilimini artırır (11). Hiperkalsemiye neden olan diğer malignite ile ilişkili maddeler kalstriyol, interlökin 1 ve 6 , TGF- $\beta$ ve tümör nekroz etmenidir (9).

Hiperkalsemi ile başvuran ALL olgularında çoğuna osteolitik lezyonlar eşlik etmektedir $(5,8$, 10). Lösemi hastalarında kemik ağrısı ve patolojik kırıklar sık görülür. Bizim olgumuzda yaygın kemik ağrıları olsa da osteolitik lezyonlar saptanmadı. Çocukluk çağında hiperkalseminin nedenlerinden biri de immobilizasyondur. Hastamızın bir süredir kırıklarından dolayı yatak istirahatinde olması hiperkalseminin immobilizasyona bağlı oldığunu ilk etapta düşündürebilir. PHT düzeyinin sıfır olması bizi paratiroid bezi kaynaklı patolojilerden uzaklaştırmıştır.

Hiperkalsemi tedavisinde; ilk basamak tedavi hastanın hidrate edilmesi olup ayrıca; furosemid ve bifosfonatlar kullanılabilir. Furosemid idrardan kalsiyum atılımı arttırarak tedaviye yardımcı olurken, bifosfonatlar ise osteoklastik etkiyi inhibe ederek kemik yıkımını engeller ve böylece kalsiyumu düzeyini azaltır ve diüretik tedavisine yanıt vermeyen hiperkalsemi tedavisinde kullanılırlar. Bifosfonatlara klinik yanıt 12-24 saat sonra gözlenir (11). Bizim olgumuzda da kalsiyum düzeyi, damardan sıvı, furosemid ve pamidronat tedavileri ile normal sınırlarına gerilemiştir.

Akut lenfoblastik lösemi daha çok anemi semptomları ve kanama bozukluğu gibi laboratuvar bulgularıla birlikte klinik bulgu verse de bazen ilk bulgu olarak hiperkalsemi ve spontan fraktürlerle karşımıza çıkabilmektedir. Çocukluk çağında hiperkalsemi etyolojisinde en sık nedenlerden malignitenin ekarte edilmesi gerektiği unutulmamalıdır.

Yazarlar arasında herhangi bir çıkar çatışması bulunmamaktadır.

\section{KAYNAKLAR}

1. McCauley LK, Martin TJ. Twenty-five years of PTHrP progress: from cancer hormone to multifunctional cytokine. J Bone Miner Res. 2012; 27: 1231-9.

2. Makras P, Papapoulos SE. Medical treatment of hypercalcaemia. Hormones (Athens). 2009; 8: 8395.

3. Lietman SA, Germain-Lee EL, Levine MA. Hypercalcemia in children and adolescents. Curr Opin Pediatr. 2010; 22: 508-15.

4. Çelik E, Özdemir GN, Tüysüz G, Taştan Y, Çam H, Celkan T. A child presenting with hypercalcemia. Turk Pediatri Ars. 2014; 49: 81-3.

5. Shimonodan $H$, Nagayama J, Nagatoshi $Y$, Hatanaka M, Takada A, Iguchi $H$, et al. Acute lymphocytic leukemia in adolescence with multiple osteolytic lesions and hypercalcemia mediated by lymphoblast-producing parathyroid hormonerelated peptide: a case report and review of the literature. Pediatr Blood Cancer. 2005; 45: 333-9.

6. Trehan A, Cheetham T, Bailey S. Hypercalcemia in acute lymphoblastic leukemia: an overview. J Pediatr Hematol Oncol. 2009; 31: 424-7.

7. Inukai $\mathrm{T}$, Hirose $\mathrm{K}$, Inaba $\mathrm{T}$, Kurosawa $\mathrm{H}$, Hama A, Inada $\mathrm{H}$, et al. Hypercalcemia in childhood acute lymphoblastic leukemia: frequent implication of parathyroid hormone-related peptide and E2AHLF from translocation 17;19. Leukemia. 2007; 21: 288-96. 
8. Türker M, Oren $\mathrm{H}$, Yilmaz S, Cakmakçi H, Demircioglu F, Irken G. Unusual presentation of childhood acute lymphoblastic leukemia: a case presenting with hypercalcemia symptoms only. J Pediatr Hematol Oncol. 2004; 26: 116-7.

9. Rankin W, Grill V, Martin TJ. Parathyroid hormonerelated protein and hypercalcemia. Cancer 1997; 80: 1564-71.
10. Ganesan P, Thulkar S, Gupta R, Bakhshi S. Childhood aleukemic leukemia with hypercalcemia and bone lesions mimicking metabolic bone disease. J Pediatr Endocrinol Metab. 2009; 22: 463-7.

11. Body JJ, Bartl R, Burckhardt P, Delmas PD, Diel IJ, Fleisch $\mathrm{H}$, et al. Current use of bisphosphonates in oncology. International Bone and Cancer Study Group. J Clin Oncol. 1998;n16: 3890-9. 